\title{
Foreign Equity Trading and Average Stock-return Volatility
}

\author{
Mehmet Umutlu ${ }^{1}$, Levent Akdeniz ${ }^{2}$ and Aslihan Altay-Salih ${ }^{2}$ \\ ${ }^{1}$ Department of Accounting and Finance, Lancaster University, Lancaster, UK and ${ }^{2}$ Faculty of Business
} Administration, Bilkent University, Ankara, Turkey

\section{INTRODUCTION}

$\mathfrak{T}$ HE increasing liberalisation of many stock exchanges and the developments in computer and telecommunications technologies in the last few decades have eased the flow of international capital, leading to growing foreign investor participation in local markets. ${ }^{1}$ Today, foreign investors in emerging markets play the role of institutional investors in developed markets (Dahlquist and Robertsson, 2001) and hold the significant portion of many traded stocks. ${ }^{2}$ However, foreign funds are blamed for being very sensitive to changes in local conditions and thus causing excess volatility in local markets (Grabel, 1995; Bae et al., 2004; Stiglitz, 2004). Yet, studies analysing the impact of foreign investor participation on return volatility provide mixed results. While De Santis and Imrohoroglu (1997), Hargis (2002), Li et al. (2011) and Esqueda et al. (2012) document volatility reduction, Kim and Singal (2000) report no significant impact of foreign investor participation on volatility. ${ }^{3}$ Hence, further investigation is required to clarify the role of foreign investor participation in the return volatility of local stocks in emerging markets. This issue is important as it has policy implications for governments. ${ }^{4}$

In the literature, foreign investor participation is handled in several ways. A number of studies link foreign investor participation with financial liberalisation and analyse the behaviour of the return volatility of local market indices in event windows around the liberalisation date (De Santis and Imrohoroglu, 1997; Bekaert and Harvey, 2000; Kim and Singal, 2000). These studies implicitly assume that liberalisation occurs at a single point in time. However, financial liberalisation is a gradual process rather than an isolated event (Bekaert and Harvey, 2002; Bekaert et al., 2003; Edison and Warnock, 2003; Bley and Saad, 2011), and its status and intensity change over time (Bae et al., 2004; McLean et al., 2011). Treating financial liberalisation as a one-time occurrence ignores its ongoing nature. Different from the previous studies dealing with the effects of financial liberalisation on volatility, Umutlu et al. (2010b) take into account the time-varying nature of the extent of the removal of restrictions on crossborder transactions. In their study, some continuous measures are employed to proxy the degree of financial liberalisation, which is an important improvement over using financial

\footnotetext{
1 See Conover (2011) for a review on investment issues in emerging markets.

2 For instance, as of October 2007, foreign investors hold 59 per cent of the total number of stocks in the Istanbul Stock Exchange, and their market capitalisation reaches 72 per cent of the free-float market capitalisation.

${ }^{3}$ Another branch of the literature analyses the effects of foreign investor participation on cross-listings (See Fernandes and Ferreira, 2008; Sarkissian and Schill, 2009; Umutlu et al., 2010a). This group of studies also provides mixed results.

${ }^{4}$ For example, Malaysia imposed restrictions on foreign capital after large amounts of it left the country during the Asian financial crisis. Later, those restrictions were removed.
} 
liberalisation dates to identify regulatory restrictions on foreign investment in equity markets. It is noteworthy that such measures represent the degree of openness to foreign investment and do not aim at representing real foreign investor participation. Analysing actual foreign investor participation measured by the trading activity of foreign investors will provide new insights about the effects of foreign investor participation on volatility; it is well documented in the literature that trading activity and volatility are related. ${ }^{5}$ Studies such as Hamao and Mei (2001), Pavabutr and Yan (2007) and Wang (2007), all of which focus on examining portfolio-level volatility, take this issue into account and search for a relationship between foreign equity trading and market volatility.

In this study, rather than proxying foreign investor participation by financial liberalisation measures, we deal with the actual involvement of foreign investors by employing foreign equity purchase and sale data to search for a relationship between foreign equity trading and average total volatility for Turkish stocks. Working with foreign equity trading data allows us to eliminate several problems, such as the imprecision involved in dating the liberalisation and in detecting effective foreign investor participation. It also brings the additional advantage of determining whether or not asymmetric effects of incoming and outgoing funds on volatility arise. In our analyses, we utilise average total volatility of stocks rather than market index volatility, which is independent of the pair-wise covariances of stock returns and is thereby a pure measure of average stock-return volatility in a country. Thus, our results on average stock-return volatility are robust to potential changes in the return covariances of stocks, without an accompanying change in their individual return variances.

Our next focal point in this study is to investigate the influence channels of foreign equity trading by decomposing total volatility into systematic and idiosyncratic components. Several types of investors with different information sets may influence the information environment of firms differently (Piotroski and Roulstone, 2004). For instance, foreign investors may engage in the production of firm-specific information and trade on the private information they have, leading to higher levels of idiosyncratic volatility. Alternatively, they may bring in new market-wide information at the local or global level, increasing these systematic volatility measures, or they may enhance the accuracy of existing market-wide information, causing a decrease. Hence, foreign equity trading may affect the components of total volatility in different ways and directions. The potential differential impact of foreign equity trading on volatility components has implications for investors as well as for financial managers. For instance, higher idiosyncratic risk implies that investors need to hold greater numbers of stocks in a portfolio to achieve a given level of diversification (Campbell et al., 2001). Any change in systematic volatility, such as in local and global volatility, may affect the decisions of financial managers because systematic risk may affect firms' cost of capital. Interestingly, no study in the literature investigates the potential effects of foreign equity trading on the components of average total volatility and on average total volatility itself.

We find that net foreign equity flow is positively related with average stock return volatility even after controlling for market return, liquidity, market development and volatility persistency effects. We also show that net equity flows affect average total volatility through local and idiosyncratic volatilities, suggesting that foreign investors engage in firm-specific and market-wide information production. Although net inflow (net equity purchase) and net outflow (net equity sale) are both positively related with idiosyncratic volatility, the relationship between net outflow and idiosyncratic volatility is significantly stronger, indicating an

\footnotetext{
${ }^{5}$ See Karpoff (1987) for a survey of the volatility-volume literature.
} 
asymmetric effect. We find similar results with the alternative order of orthogonalisation in the volatility decomposition process and with the alternative model-independent definition of idiosyncratic volatility. Our results can be explained from the asymmetric information-based perspectives of Kyle (1985) and Admati and Pfleiderer (1988). ${ }^{6}$ The main assertion in the asymmetric information models is that net order or trade flow (imbalance) signals the extent of information asymmetry between informed and uninformed traders because if the informed traders are confident in the information they have, their trades will bunch on one side of the trading and create an imbalance. Thus, net order or trade flow is an indicator of the quality of private information. When informed trading takes place, private information is incorporated into stock prices, which induces volatility.

The remainder of the paper is organised as follows: Section 2 describes foreign investors in the Istanbul Stock Exchange (ISE). Section 3 defines the data and the estimation methodology for volatility measures. Section 4 examines the relationship between average total volatility and foreign equity trading. Section 5 investigates the volatility components of average total volatility as potential channels of influence for foreign equity trading. Section 6 checks the robustness of the results. The final section concludes the paper.

\section{FOREIGN INVESTORS IN THE ISTANBUL STOCK EXCHANGE}

The ISE is an interesting stock exchange for investigating the effects of foreign equity investment due to its distinguishing characteristics. ${ }^{7}$ Its Decree No. 32, passed in August 1989, is a policy that aims at facilitating foreign institutional and individual investments in securities listed on the ISE. The decree removes all restrictions on the repatriation of capital and profits for foreign institutional and individual investors; hence, there are no restrictions on foreign portfolio investors trading in the Turkish securities markets and the ISE is fully open to foreign investors. ${ }^{8}$ After these regulations, foreign investors actively participated in the ISE with an increasingly important role. ${ }^{9}$ Figure 1 shows the shares of foreign investors in portfolio size and volume. As of December 2006, the market capitalisation of foreign holdings had reached 68 per cent of the market capitalisation of the free-floated shares. The size of foreign investors' portfolio shares exhibits an increasing trend since 2003. This ratio was 51 per cent in 2003, 61 per cent in 2004 and 67 per cent in 2005. In the last two years of our study period, foreign investors held about two-thirds of the free-floated shares. Despite their large portfolio value, foreign investors' contribution to the volume in terms of value traded is limited. Although the value traded by foreign investors in the last two years of the research period was at the highest levels ever, the majority of volume in the market is still due to the transactions of domestic investors. As of 2006, domestic investors contributed 81 per cent of the ISE's total volume and therefore are the main providers of liquidity. This is consistent with

\footnotetext{
${ }^{6}$ Since the Netflow variable is a changes-based measure, we rule out other potential explanations, such as the investor-broadening hypothesis, which is a levels-based conjecture.

${ }^{7}$ Detailed information about the regulatory rules on foreign investors can be found on the ISE's website: www.ise.org.

8 Decree No. 32 also allows Turkish citizens to buy foreign securities.

9 The information in this section is mainly based on the several annual reports of The Association of Capital Market Intermediary Institutions of Turkey. For a more comprehensive survey on investor profiles in the ISE, the reader is referred to the annual reports (The Association of Capital Market Intermediary Institutions of Turkey, 2007; 2008), which can be found on the website of the institution: http://www.tspakb.org.tr.
} 
FIGURE 1

Foreign Investors' Shares of Portfolio Size and Volume in Terms of Value Traded

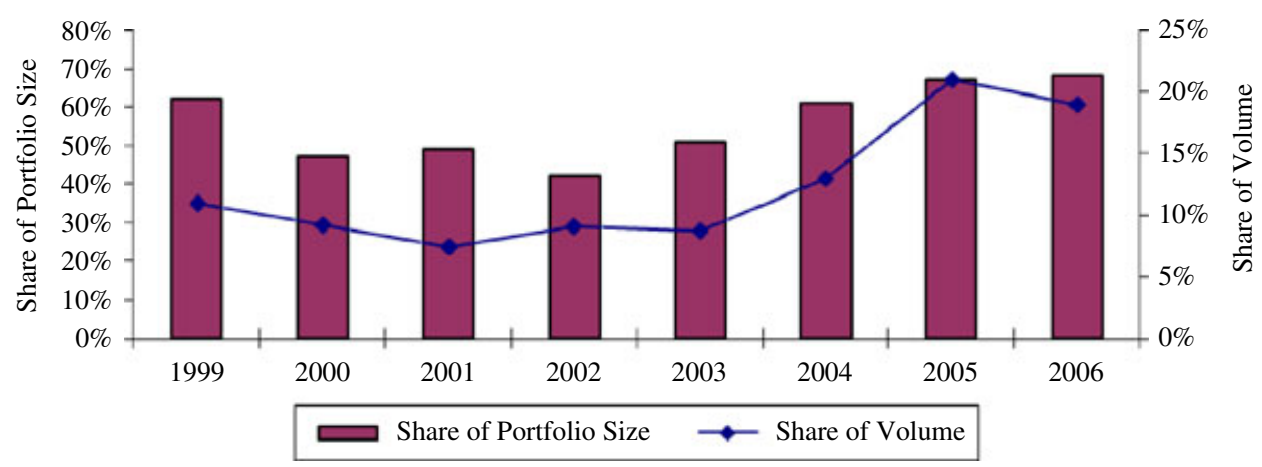

Rhee and Wang (2009), who show an adverse effect of foreign holdings on stock liquidity in Indonesia.

Variations in foreign investors' portfolio value, volume and net equity flow overtime, along with some basic market characteristics such as local index return and exchange rate return are presented in Table 1 . The table demonstrates that the value of the foreign equity portfolio and the volume by foreign investors decreased between 1999 and 2002. Negative growth prospects after a devastating earthquake in the most industrialised region of Turkey in 1999 and the financial crises in 2001 and 2002 may have been responsible for this drop. Foreign investors began to increase their participation in 2003 and reached maximum levels in the value of equity portfolios in 2006 and in trading activity in 2005. High foreign trading volume in 2005 may have been associated with channelled equity flows to Turkey as a result of favourable economic conditions globally. ${ }^{10}$ It is reported that US $\$ 362$ billion of capital flowed to emerging countries in 2005 and that Turkey ranked fifteenth in stock market performance and fifth in turnover rate among emerging markets for the same year (Standard and Poor's, 2006). It seems that the Turkish stock market's relatively high performance and low liquidity risk attracted the attention of foreign investors. Conversely, high trading volume in 2000 may have been due to trades of foreigners leaving the market who had received warnings of the looming financial crises.

To understand the possible sources of foreign equity portfolio returns and foreign trading activity, we present annual local index and exchange rate returns in the last two columns of Table 1, respectively. It is evident from the table that the value of the foreign equity portfolio shrinks during years when the ISE National-100 Index return exhibits a loss and, conversely, it increases during positive-return years. Exchange rate return is the annual percentage change of the foreign exchange value of the Turkish lira against the US dollar, where end-of-period levels of effective rates are used in the calculations. A negative (positive) exchange rate return indicates that the Turkish lira appreciated (depreciated) against the US dollar and one would have incurred a loss (gain) by investing in US dollars for the relevant period. We do not observe a notable pattern between exchange rate return and portfolio size or volume; however,

10 The global growth rate was 4.4 per cent in 2005, with the highest growth rates in emerging economies (Standard and Poor's, 2006). 
TABLE 1

Foreign Equity Investment (mil. \$) and Some Market Characteristics

\begin{tabular}{lllllllll}
\hline & $\begin{array}{l}\text { Equity } \\
\text { Portfolio } \\
\text { Value }\end{array}$ & $\begin{array}{l}\text { Trading } \\
\text { Volume }\end{array}$ & $\begin{array}{l}\text { Public } \\
\text { Offering } \\
\text { Purchase }\end{array}$ & $\begin{array}{l}\text { Secondary } \\
\text { Market Net } \\
\text { Purchase/Sale }\end{array}$ & $\begin{array}{l}\text { Net Equity } \\
\text { Inflow/ } \\
\text { Outflow }\end{array}$ & $\begin{array}{l}\text { Gain/ } \\
\text { Loss }\end{array}$ & $\begin{array}{l}\text { Return on } \\
\text { ISE-100 } \\
\text { Index (\%) }\end{array}$ & $\begin{array}{l}\text { Exchange } \\
\text { Rate } \\
\text { Return (\%) }\end{array}$ \\
\hline 1999 & 15,358 & 17,879 & 10 & 1,024 & 1,034 & 10,624 & 240 & 71.33 \\
2000 & 7,404 & 33,410 & 2,677 & $-3,134$ & -457 & $-7,497$ & -50 & 23.51 \\
2001 & 5,635 & 12,139 & 10 & 509 & 519 & $-2,288$ & -32 & 113.84 \\
2002 & 3,450 & 12,869 & 64 & -15 & 49 & $-2,234$ & -34 & 13.11 \\
2003 & 8,954 & 17,334 & 82 & 1,010 & 1,092 & 4,412 & 111 & -15.35 \\
2004 & 16,141 & 37,368 & 950 & 1,430 & 2,380 & 4,807 & 40 & -4.93 \\
2005 & 33,812 & 83,275 & 1,477 & 3,989 & 5,466 & 12,205 & 59 & -0.72 \\
2006 & 35,083 & 88,519 & 600 & 1,144 & 1,744 & -473 & -6 & 3.93 \\
\hline
\end{tabular}

Sources: The Association of Capital Market Intermediary Institutions of Turkey (2007) and the authors' own calculations.

it is noteworthy that the exchange rate return moves in the opposite direction from the net value appreciation of the foreign equity portfolio and from the ISE National-100 Index return. The value of the foreign equity portfolio increases when the Turkish lira appreciates against the US dollar and vice versa. A strong lira may be perceived as an indicator of a strong economy and may enhance the confidence of foreign investors in growth expectations. This increased confidence may lead to increases in stock and index prices and thus in the size of the foreign equity portfolio.

In Table 1, it is also apparent that the value of the foreign equity portfolio increased more than US\$32 billion between 2002 and 2006. Foreign investors' portfolio values at the end of 2002 , which were the values of their portfolio at the beginning of 2003 , were US $\$ 3,450$ million. In 2003, foreign investors purchased stocks worth US\$82 million from public offerings and worth US\$1,010 million from the secondary market. Thus, net equity inflow in 2003 was US $\$ 1,092$ million. If market prices had remained constant throughout 2003, the value of Turkey's foreign equity portfolio would be US $\$ 4,542$ million $(=3,450+1,092)$. However, the table shows that the value at the end of 2003 was US $\$ 8,954$ million; hence, it appreciated by US $\$ 4,412$ million $(=8,954-4,542)$. Similar calculations for the remaining years reveal that the increase of US $\$ 32$ billion since 2002 stems from US $\$ 21$ billion of appreciation in the value of the portfolio and US\$11 billion of equity inflow. Therefore, the main increase is due to appreciation, which may partly explain the increasing interest of foreign investors in the ISE.

The Net Equity Inflow/Outflow column of Table 1 shows that foreign investors were net buyers of Turkish stocks between 2001 and 2006. The inflow of equity concentrated over the last four years, with a total amount of US\$10.7 billion. The Gain/Loss column of Table 1 shows time variations in the foreign portfolio value; between 2000 and 2002, it lost US\$12 billion. On the other hand, foreign investors experienced a gain of US\$21 billion between 2003 and 2005. In 2006, the value of the foreign portfolio fell slightly. In the long run, that is, between 1999 and 2006, foreigners experienced a net gain of US\$19.5 billion.

Turnover rate is another noteworthy characteristic of foreign investors and gives an idea about the investment horizon of foreign investors in the ISE. The Association of Capital Market Intermediary Institutions of Turkey defines Turnover Rate as the number of times a 
TABLE 2

Comparison of Foreign and Domestic Investors

\begin{tabular}{|c|c|c|c|c|c|c|}
\hline & \multicolumn{2}{|c|}{$\begin{array}{l}\text { Average Portfolio Size } \\
\text { (mil. \$) }\end{array}$} & \multicolumn{2}{|c|}{$\begin{array}{l}\text { Annual Turnover (Value } \\
\text { Traded, mil. \$) }\end{array}$} & \multicolumn{2}{|c|}{ Turnover Rate } \\
\hline & Foreign & Domestic & Foreign & Domestic & Foreign & Domestic \\
\hline 1999 & 6,927 & 4,539 & 17,879 & 150,188 & 2.58 & 33.09 \\
\hline 2000 & 11,440 & 12,643 & 33,410 & 330,457 & 2.92 & 26.14 \\
\hline 2001 & 4,849 & 6,756 & 12,139 & 148,661 & 2.50 & 22.01 \\
\hline 2002 & 4,265 & 4,842 & 12,869 & 128,644 & 3.02 & 26.57 \\
\hline 2003 & 5,069 & 5,790 & 17,334 & 182,997 & 3.42 & 31.61 \\
\hline 2004 & 10,603 & 9,363 & 37,368 & 258,142 & 3.52 & 27.57 \\
\hline 2005 & 22,354 & 13,293 & 83,275 & 322,426 & 3.73 & 24.25 \\
\hline 2006 & 33,815 & 17,311 & 88,519 & 370,766 & 2.62 & 21.42 \\
\hline
\end{tabular}

Source: The Association of Capital Market Intermediary Institutions of Turkey (2007).

portfolio is rebalanced in a year and calculates it as the ratio of Annual Turnover in terms of value traded to Average Portfolio Size, which is the equal weighted average of end-of-the month portfolio values in a year. A portfolio is rebalanced (Turnover Rate) $/ 2$ times in a year. The Average Portfolio Size, Annual Turnover and Turnover Rate of foreign and domestic investors are provided in Table 2. The average turnover rate of foreign investors is 3.04 during the sample period, indicating that foreign investors changed their portfolio 1.52 times in a year. On the other hand, domestic investors' average turnover rate is 26.58 , indicating 13.29 portfolio rebalancings in a year. As domestic investors rebalance their portfolios much more frequently than foreign investors, their average holding period is much shorter. This fact suggests a shorter investment horizon for domestic investors.

In summary, foreign investors are distinguished from domestic investors in Turkey in several ways. Foreign investors hold the majority of the traded stocks in the ISE. They hold their portfolios for a relatively long period and provide limited liquidity to the market. They have experienced important increases in their portfolio values in the last few years, mainly due to appreciation. Net gains in foreigners' portfolio values in the medium and long terms and the positive growth prospects of the Turkish economy may attract further foreign equity investment. For these reasons, it is likely that foreign investors will maintain their important role in the ISE.

\section{METHODOLOGY AND DATA}

\section{a. Volatility Decomposition and the Estimation of Volatility Measures}

Campbell et al. (2001) and Ferreira and Gama (2005) decompose volatility in such a way that the volatility components do not contain covariance and individual beta terms, and thus, estimation problems such as inaccuracy (Fama and MacBeth, 1973) and time-variability are eliminated. Umutlu et al. (2010b) extend this volatility decomposition method to a modified market model. The differentiating feature of the decomposition of Umutlu et al. (2010b) over the decompositions of Campbell et al. (2001) and Ferreira and Gama (2005) is its ability to examine the effects of local and global factors simultaneously, permitting the consideration of 
the conditional effect of one factor given the other. In this study, we follow the volatility decomposition proposed by Umutlu et al. (2010b) to decompose average total volatility into its systematic and unsystematic constituents. Hence, we can investigate the channels of influence for average total volatility.

The decomposition is based on a two-factor model with local and global factors, and a variant of a market-adjusted model of Campbell et al. (2001). The basic assumption is that a local market portfolio contributes to the systematic risk of the global market portfolio proportionally with its covariance with the global market portfolio. In technical terms:

$$
\tilde{R}_{l t}=\beta_{l w} \tilde{R}_{w t}+\tilde{\varepsilon}_{l t},
$$

where $\tilde{R}_{l t}$ and $\tilde{R}_{w t}$ are the monthly returns on local and global market indices, respectively, $\beta_{l w}$ is the slope coefficient of the regression equation and $\tilde{\varepsilon}_{l t}$ is the residual term, which represents the return on the local market portfolio that is orthogonal to the return on the global market portfolio. Next, the return of an individual stock is formulated to be driven by global factors and local factors that are orthogonal to global factors in a modified market model framework:

$$
\tilde{R}_{i t}=\beta_{i w} \tilde{R}_{w t}+\beta_{i l} \tilde{\varepsilon}_{l t}+\tilde{\varepsilon}_{i t},
$$

where $\tilde{R}_{i t}$ is the monthly return of stock $i$, $\tilde{\varepsilon}_{l t}$ is the residual term from equation (1), $\beta_{i w}=\operatorname{cov}\left(\tilde{R}_{w t}, \tilde{R}_{i t}\right) / \operatorname{var}\left(\tilde{R}_{w t}\right), \beta_{i l}=\operatorname{cov}\left(\tilde{\varepsilon}_{l t}, \tilde{R}_{i t}\right) / \operatorname{var}\left(\widetilde{\varepsilon}_{l t}\right), \tilde{\varepsilon}_{i t}$ is the residual term of equation (2) and $\tilde{R}_{l t}=\sum_{i \in l} w_{i t} \tilde{R}_{i t}$.

The market-adjusted model, $R_{i t}=R_{l t}+\varepsilon_{i t}$, of Campbell et al. (2001) is substituted in equation (1) to obtain volatility components that do not contain covariance and individual beta terms. Thus, the estimation of these parameters, which may be time-varying and imprecise over time, is eliminated.

$$
\tilde{R_{i t}}=\beta_{l w}{\tilde{R_{w t}}}+\tilde{\varepsilon}_{l t}+\varepsilon_{i t}
$$

Here, the return on stock $i$ is the sum of the return on the global market portfolio inflated by $\beta_{l w}$, a country-specific residual and a firm-specific residual. From the equality of equations (2) and (3), we have the following link between the modified market model and the marketadjusted model.

$$
\varepsilon_{i t}=\left(\beta_{i w}-\beta_{l w}\right) \tilde{R}_{w t}+\left(\beta_{i l}-1\right) \tilde{\varepsilon}_{l t}+\tilde{\varepsilon}_{i t}
$$

The return variance of an individual stock is expressed by the variance of equation (3) as follows:

$$
\operatorname{var}\left(\tilde{R}_{i t}\right)=\beta_{l w}^{2} \operatorname{var}\left(\tilde{R}_{w t}\right)+\operatorname{var}\left(\widetilde{\varepsilon}_{l t}\right)+\operatorname{var}\left(\varepsilon_{i t}\right)+2 \beta_{l w} \operatorname{cov}\left(\tilde{R}_{w t}, \varepsilon_{i t}\right)+2 \operatorname{cov}\left(\widetilde{\varepsilon}_{l t}, \varepsilon_{i t}\right) .
$$

After substituting equation (4) into equation (5) for covariance terms only and rearranging, the return variance of an individual stock can be expressed in the following form:

$$
\operatorname{var}\left(\tilde{R}_{i t}\right)=\left(2 \beta_{l w} \beta_{i w}-\beta_{l w}^{2}\right) \operatorname{var}\left(\tilde{R}_{w t}\right)+\left(2 \beta_{i l}-1\right) \operatorname{var}\left(\tilde{\varepsilon}_{l t}\right)+\operatorname{var}\left(\varepsilon_{i t}\right) .
$$

Finally, the stock-return variances are averaged over individual stocks to reach the average total volatility in a stock market for month $t$. 


$$
\begin{aligned}
\sum_{i} w_{i t} \operatorname{var}\left(\tilde{R}_{i t}\right)= & \left(2 \beta_{l w} \sum_{i} w_{i t} \beta_{i w}-\beta_{l w}^{2}\right) \operatorname{var}\left(\tilde{R}_{w t}\right) \\
& +\left(2 \sum_{i} w_{i t} \beta_{i l}-1\right) \operatorname{var}\left(\tilde{\varepsilon}_{l t}\right)+\sum_{i} w_{i t} \operatorname{var}\left(\varepsilon_{i t}\right) .
\end{aligned}
$$

The average return volatility of stocks in a country is decomposed into its components by expressing the market-adjusted model in terms of the modified market model as follows:

$$
\begin{aligned}
\sum_{i} w_{i t} \operatorname{var}\left(\tilde{R}_{i t}\right) & =\beta_{l w}^{2} \operatorname{var}\left(\tilde{R}_{w t}\right)+\operatorname{var}\left(\tilde{\varepsilon}_{l t}\right)+\sum_{i} w_{i t} \operatorname{var}\left(\varepsilon_{i t}\right) \\
\sigma_{a_{l t}}^{2} & =\text { Global }+ \text { Local }+ \text { Idiosyncratic }
\end{aligned}
$$

Here, $\sigma_{a_{l t}}^{2}=\sum_{i} w_{i t} \operatorname{var}\left(\tilde{R}_{i t}\right)$, Global $=\hat{\beta}_{l w}^{2} \operatorname{var}\left(\tilde{R}_{w t}\right)$, Local $=\operatorname{var}\left(\tilde{\varepsilon}_{l t}\right)$, and Idiosyncratic $=$ $\sum_{i} w_{i t} \operatorname{var}\left(\varepsilon_{i t}\right)$.

Average volatility measures are definitely not portfolio-level volatility measures and are constructed by averaging (aggregating) individual total or idiosyncratic stock return volatilities. In other words, these measures are average volatility measures characterising the total volatility or idiosyncratic volatility of a 'typical' stock and do not measure the volatility of a portfolio. In our study, average total volatility is the weighted average of monthly return variances of stocks in the S\&P/IFC Global Index of Turkey. We focus on average volatility rather than portfolio volatility for two reasons. First, we are dealing with the question of whether foreign equity investment affects stock-return volatility on average. Studying average stock-return volatility is important since changes in average stock-return volatility have financial implications, possibly affecting firms' cost of capital. Studies analysing the return volatility of portfolios do not provide a clear answer about average stock return volatility. Second, average total volatility may be decomposed into systematic volatility and average idiosyncratic volatility, which further enables us to study the effects of net equity flow on average idiosyncratic volatility and systematic volatility. On the other hand, in a portfolio-level analysis, investigation of idiosyncratic volatility has limited scope as idiosyncratic risk is largely diversified away.

Next, we estimate average volatility and its components for empirical implementation. ${ }^{11}$ Let $s$ refer to the days over which returns are calculated and let $t$ refer to the month in which the volatility estimates are constructed. The monthly volatility of a stock is computed as:

$$
\operatorname{var}\left(\tilde{R}_{i t}\right)=\sum_{s \in t}\left(R_{i s}-\mu_{i t}\right)^{2}
$$

where $\mu_{i t}$ is the mean return of stock $i$ at time $t$.

The weighted average of return volatilities of all stocks in the SP/IFC Global Index of Turkey at month $t$ is the estimated average total volatility measure for that month, where the weights are based on the market capitalisation of firms which are also drawn from the S\&P/IFC Global Index of Emerging Markets Database (EMDB).

\footnotetext{
${ }^{11}$ We calculate monthly variances by using daily data. The daily variance, which is the variance of daily returns within a month, is converted to monthly variance by multiplying the daily variance with the number of trading days, $n$, within a month. So, in monthly variance calculations, the sum of squared deviations has the multiplier of $n /(n-1)$ rather than $1 /(n-1)$, which is close to 1 . Therefore, the estimates of monthly variances reduce to the sum of squared deviations.
} 


$$
\sum_{i} w_{i t} \operatorname{var}\left(\tilde{R}_{i t}\right)=\sum_{i} w_{i t}\left(\sum_{s \in t}\left(R_{i s}-\mu_{i t}\right)^{2}\right)
$$

We proceed with estimating the components of the average total volatility. The estimated global volatility (denoted as Global) within period $t$ is computed as follows:

$$
\text { Global }=\hat{\sigma}_{w t}=\hat{\beta}_{l w}^{2}\left(\sum_{s \in t}\left(R_{w s}-\mu_{w t}\right)^{2}\right),
$$

where $\mu_{w t}$ is the mean of the global-index return and $\hat{\beta}_{l w}$ is the estimated regression coefficient of equation (1) within a month, calculated by using daily return data. We estimate local volatility by summing up the squares of the country-specific residuals of equation (1) within period $t$, in the following manner:

$$
\text { Local }=\hat{\sigma}_{\varepsilon_{l}}^{2}=\sum_{s \in t} \hat{\varepsilon}_{s}^{2}
$$

To estimate the average idiosyncratic volatility, we first calculate the idiosyncratic volatility individually for each stock by summing up the squares of the firm-specific residuals of equation (3) within period $t$ :

$$
\operatorname{var}\left(\varepsilon_{i t}\right)=\sum_{s \in t} \hat{\varepsilon}_{i s}^{2} .
$$

Value weighting the idiosyncratic volatility estimates of individual stocks, we come up with the estimated average idiosyncratic volatility:

$$
\text { Idiosyncratic }=\hat{\sigma}_{\varepsilon_{i t}}^{2}=\sum_{i} w_{i t} v \hat{a} r\left(\varepsilon_{i t}\right) .
$$

\section{b. Data}

Our data comprise returns of stocks that are listed in the Standard \& Poor's/International Finance Corporation (S\&P/IFC) Global Index of Turkey from January 1997 to June 2006. Each month of the research period, monthly return variances of firms listed in the S\&P/IFC Global Index of the EMDB were computed using the daily adjusted closing prices in US dollars. All the IFC Global Index firms of Turkey form our sample. The closing prices of the local index (ISE-100) and the world market index (World-DS Market) come from EMDB and Datastream, respectively. We obtain foreign investor trading data from the ISE in terms of aggregate monthly purchases and sales by foreign investors. We define a monthly flow variable (Netflow) as the difference between the values of foreign purchases and sales, normalised by the value of foreign investors' shares in the free-float market capitalisation. We analyse the impact of net equity flows on the average total volatility and its components under the control of some volatility determinants. In a falling (rising) market, foreign sellers (purchasers) may simply be sellers (purchasers) among a crowd of sellers (purchasers). Due to this possibility, net foreign equity flow may be capturing market-wide price impacts. To handle this issue, we control for the market return, which is the monthly return of the S\&P/IFC Global Index of Turkey. To account for liquidity effects, we use turnover ratio (TO) which is the ratio of the total value of shares traded during the period to the average market capitalisation for the period. Average market capitalisation is calculated as the average of the end-of-period values for the current period and the previous period. We consider the effect of stock market 
development on volatility by the variable Size, which is the ratio of market capitalisation of the stock market to the GDP of the country. The lagged values of the aggregated total volatility are also included as explanatory variables, to account for a possible persistency in volatility. The data for the $T O$ and stock market capitalisation are taken from EMDB, whereas GDP data are obtained from the World Bank.

Figure 2 shows the time variation of average total volatility, where returns are calculated in dollars. The volatile times appearing on the graph correspond to major financial crises (one in 1999 and one in 2001) and exchange-rate turbulence in 2006. Figure 2 shows that the average volatility measure does a good job in capturing the average volatility.

Figure 3 shows the time variation of volatility components as a percentage of total volatility through time. It is observed that total volatility is dominated especially by local volatility. As stated previously, Turkey experienced a few crises in the last decade, and their impact on the overall economy was severe. The crises show their effects as an increase in the average total volatility, but most importantly, the fraction of the total volatility that is represented by the local market volatility increased during these times. Because the crises systematically

\section{FIGURE 2}

Average Total Volatility Through Time. Weighted Average of Stock Return Volatility Computed in Dollars

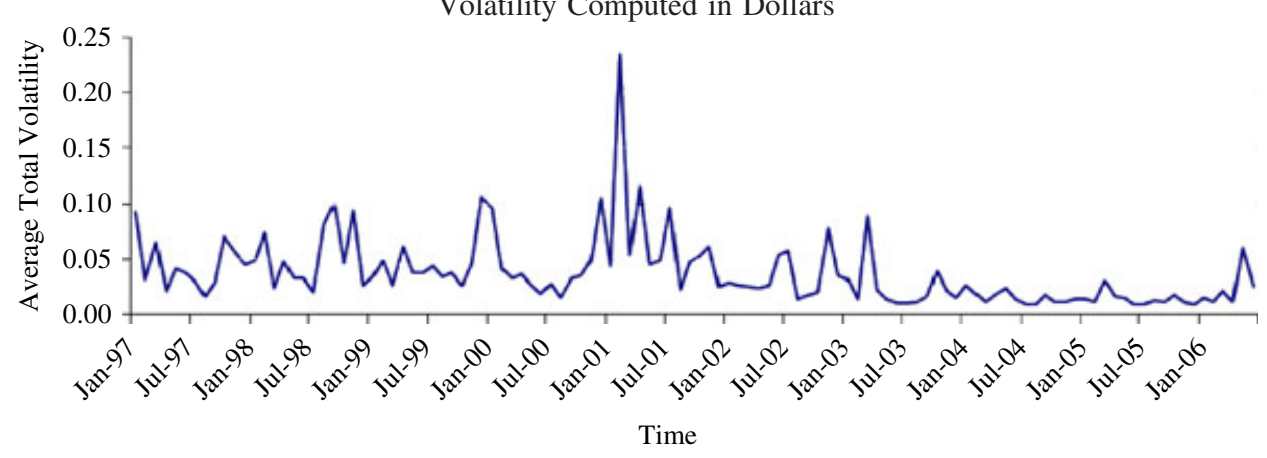

FIGURE 3

Proportion of Volatility Components. Time Variation of Volatility Components as a Percentage $100 \%$ of Average Total Volatility through Time

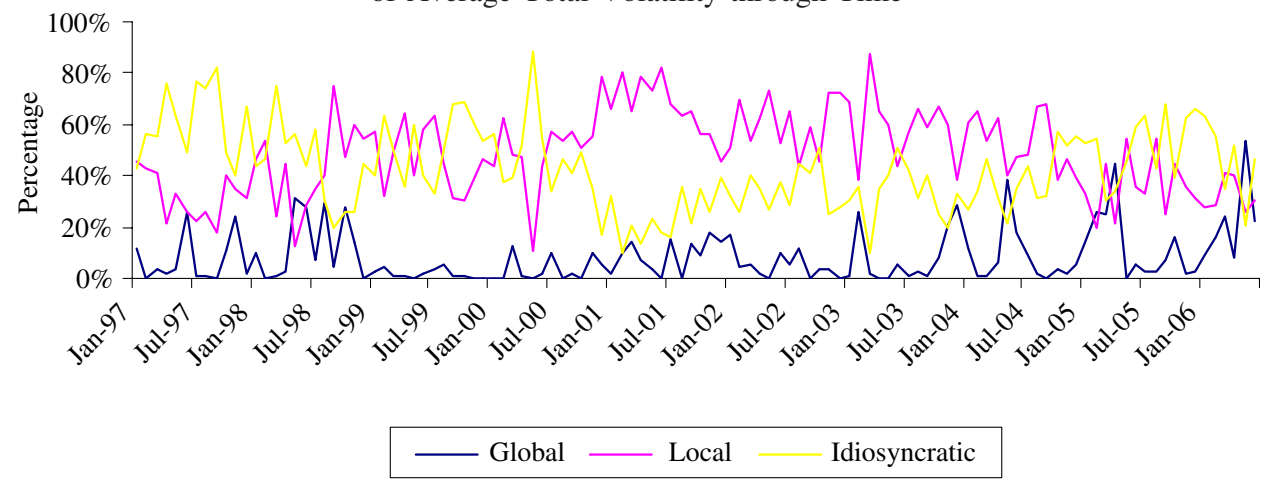


affected all the firms, it is reasonable to observe such an increase in the share of local volatility during the crisis periods. On the other hand, the contribution of the global volatility to total volatility is limited; however, Figure 3 also shows that it slightly increased its share after 2001. This increase in global volatility is consistent with the increased foreign participation in the ISE during the last five years. As foreign investors trade more heavily in the ISE, it is expected that the ISE will become more integrated with the global market and that the volatility, due to global factors, will increase.

Some descriptive information for the volatility measures, net equity flow and the control variables are provided in Table 3. A high variation of Netflow during the research period is noted. The mean of the ratio of net equity flow is 0.003 , while the standard deviation is 0.023 , which is more than seven times the mean. Inspection of the mean levels of the volatility components reveals that the maximum contribution to the total volatility is made by Local, with a mean level of 0.020 , confirming the graphical results of Figure 3. Not surprisingly, average total volatility and Local are highly correlated, with a correlation coefficient of 0.933. Idiosyncratic makes the second largest contribution to average total volatility, with a mean level of 0.015 . Global is a very small portion of the total volatility and has a mean of 0.003. Netflow is negatively related with all the volatility measures, whereas TO is positively related. The direction of the relation between volatility measures and Return and the direction of the relation between volatility measures and Size are not uniform and depend on the specific volatility measure used. All variables except Global, Netflow and Return are highly persistent with a significant Ljung-Box statistic for three monthly lags at the 5 per cent significance level, indicating that the null hypothesis of no autocorrelation up to order 3 is rejected. This raises the possibility of unit roots in the persistent variables. To check this issue, we employ a unit root test with an intercept in the test equation. The hypothesis of a unit root is rejected for all variables at the traditional significance levels. Consequently, series in levels rather than differences are used in our analyses.

\section{AVERAGE TOTAL VOLATILITY AND FOREIGN EQUITY TRADING}

In this part, we empirically test the hypothesis that foreign equity trading does not affect the average total volatility of stocks. For this purpose, we regress $\sum_{i \in l} w_{i} \operatorname{var}\left(\tilde{R}_{i t}\right)=\sigma_{a t}^{2}$ on net equity flow, Netflow, the absolute value of net equity flow, $\mid$ Netflow $\mid$ and other control variables. More specifically, the following time-series regression model is estimated:

$$
\begin{aligned}
\hat{\sigma}_{a t}^{2}=c & +\beta_{1} \text { Netflow }_{t}+\beta_{2} \mid \text { Netflow }_{t} \mid+\beta_{3} \text { Return }_{t}+\beta_{4} \mid \text { Return }_{t} \mid \\
& +\beta_{5} \text { Size }_{t}+\beta_{6} \text { TO }_{t}+\beta_{7} \hat{\sigma}_{a, t-1}^{2}+\beta_{8} \hat{\sigma}_{a, t-2}^{2}+\beta_{9} \hat{\sigma}_{a, t-3}^{2}+\beta_{10} \hat{\sigma}_{a, t-4}^{2}+\eta_{t},
\end{aligned}
$$

where $t$ denotes month $(t=1,2, \ldots \mathrm{T}), \sum_{i \in l} w_{i} \operatorname{var}\left(\tilde{R}_{i t}\right)=\sigma_{a t}^{2}$ is the weighted average of return volatilities of the stocks in the S\&P/IFC Global Index of Turkey, Netflow is the difference between the foreign purchases and sales divided by the value of foreign investors' portfolio, Return is the monthly return on the S\&P/IFC Global Index of Turkey, Size is the market capitalisation of the stock market as a share of the GDP and TO is the turnover ratio for the stock market. The lagged values of the average total volatility account for possible persistency in volatility. In addition to Netflow, we include $\mid$ Netflow $\mid$ in the regression equation to detect whether an asymmetric effect of inflows and outflows on volatility emerges. When Netflow is positive in value, that is, foreign investors are net buyers of local stocks, then the effect of net flow (inflow) on volatility is $\beta_{1}+\beta_{2}$. When Netflow is negative in value, that is, foreign 
TABLE 3

Descriptive Statistics

\begin{tabular}{lccccccccc}
\hline \multicolumn{1}{c}{} & $\begin{array}{l}\text { Average Total } \\
\text { Vol. }\end{array}$ & Local & Global & Idiosyncratic & Netflow & Return & TO & Size \\
\hline Mean & 0.038 & 0.02 & 0.003 & 0.015 & 0.003 & 0.026 & 0.142 & 0.293 \\
Std. Dev. & 0.031 & 0.024 & 0.005 & 0.013 & 0.023 & 0.18 & 0.053 & 0.112 \\
Median & 0.028 & 0.014 & 0.001 & 0.011 & 0.005 & 0.015 & 0.134 & 0.271 \\
Min. & 0.008 & 0.002 & 0 & 0.003 & -0.097 & -0.407 & 0 & 0.126 \\
Max. & 0.234 & 0.195 & 0.031 & 0.112 & 0.054 & 0.713 & 0.385 & 0.628 \\
$\rho(1)$ & 0.277 & 0.231 & 0.134 & 0.313 & 0.198 & -0.060 & 0.306 & 0.868 \\
Q(3) & $38.08^{* * *}$ & $41.36^{* * *}$ & $7.44^{*}$ & $23.84^{* * *}$ & $6.44^{*}$ & 2.35 & $13.91^{* * *}$ & $224.12^{* * *}$ \\
Unit root test & -8.76 & -9.28 & -9.38 & -8.70 & -8.74 & -11.67 & -7.68 & -2.71 \\
& {$[0.00]$} & {$[0.00]$} & {$[0.00]$} & {$[0.00]$} & {$[0.00]$} & {$[0.00]$} & {$[0.00]$} & {$[0.08]$} \\
Correlation & & & & & & & & \\
Local & 0.933 & & & & & & & & \\
Global & 0.546 & 0.446 & & & & & & \\
Idiosyncratic & 0.423 & 0.251 & 0.065 & & & & & \\
Netflow & -0.293 & -0.231 & -0.242 & -0.339 & & & & \\
Return & -0.026 & -0.116 & -0.278 & 0.084 & 0.406 & & & \\
TO & 0.115 & 0.133 & 0.013 & 0.017 & -0.066 & 0.397 & & \\
Size & 0.052 & -0.002 & -0.104 & 0.325 & -0.169 & 0.172 & 0.122 & \\
\hline
\end{tabular}

Notes:

(i) Average Total Volatility is the weighted average of monthly return volatilities of stocks in the S\&P/IFC Global Index of Turkey. Local is the monthly residual variance, where the residuals are obtained by the regression of the local index return on the global index return. Global is defined as the monthly return variance of the global index, inflated by the square of beta of the local index return with respect to the global index return. Idiosyncratic represents the average residuals variance, where residuals are obtained by the two-factor market-adjusted model with the local and global factors. Netflow is the difference between the values of total foreign purchases and sales, normalised by the value of foreign investors' shares of the free-float market capitalisation. Return is calculated using the total return series of S\&P/IFC Global Index of Turkey. TO is the turnover ratio of the stock market in terms of value traded and accounts for the liquidity effects. Size is the total market capitalisation of the stock market as a share of GDP, and it reflects the level of market development. $\rho(1)$ is a first-order autocorrelation. (ii) Q(3) is the Ljung-Box statistic for the null hypothesis that there is no autocorrelation up to order 3. (iii) The brackets show the $p$ values of the unit root test with an intercept, which examines the null hypothesis that the series has a unit root.

(iv) and $* * *$ represent $10 \%$ and $1 \%$ significance levels, respectively.

investors are net sellers of local stocks, the effect of net flow (outflow) on volatility is $-\beta_{1}+\beta_{2}$. If $\beta_{1}$ turns out to be significantly negative, $-\beta_{1}$ results in a positive value, and thus net equity outflows have a boosting impact on volatility. With similar logic, the absolute value of market return (|Return|) enters the regression equation to detect whether volatility behaves differently in times of falling and rising markets, as it is debated whether negative returns cause a higher volatility than positive returns do. As in the case of the coefficient interpretation of net flow, we deduce that an asymmetric effect of positive and negative returns manifests itself if the coefficient of Return is significantly negative.

We use the generalised method of moments (GMM) to estimate the model. This method does not make any distributional assumptions, such as normality, and as we deal with volatilities, this issue is especially important in our study. ${ }^{12}$ Moreover, GMM generates

12 As the GMM estimation framework allows working with non-normal variables, no transformation (such as the logarithmic transformation) is applied to the dependent variables. 
heteroscedasticity and autocorrelation consistent (HAC) standard errors that are robust to arbitrary forms of heteroscedasticity and autocorrelation. More importantly, a GMM estimation framework facilitates addressing possible simultaneity and endogeneity issues. In this study, our focus is on the effect of foreign trading on volatility. However, as foreign investors may time their trading to exploit favourable market conditions such as low volatility or high return periods, a reverse causality may exist between stock return volatility and foreign equity trading. Additionally, our regression models are dynamic, where the lagged values of the dependent variable are included to explain the dependent variable. In dynamic regression models, the endogeneity problem is particularly relevant due to the use of lagged-dependent variables as explanatory variables. If one or more variables are simultaneously or endogeneously determined in our regression models, then one of the assumptions of ordinary least squares (OLS) estimation (that explanatory variables and error terms are uncorrelated) is violated. If that is the case, the OLS estimates will be biased. To cope with this possible problem, we employ instruments for foreign equity trading, return and lagged volatilities. We use the lags of the explanatory variables up to four periods as the instrumental variables. We perform the $J$-test for over-identifying restrictions to determine whether the instruments we adopt are valid. Table 4 presents the estimation results of the regression of average total volatility on net foreign equity trading, along with some control variables in different combinations.

In Table 4, a highly significant and robust positive effect of |Netflow| on average total volatility is reported under different specifications, whereas a negative insignificant effect of Netflow is observed. For the full specification (Model IV), one standard deviation positive change in the absolute value of net flow causes the average total volatility to increase by $0.021(=0.893 \times 0.023)$, which is more than half the sample mean of average total volatility, or 0.038 . In other words, $\mid$ Netflow $\mid$ increases volatility significantly in statistical and in economic terms. The insignificant coefficient for Netflow shows that the impact of net outflows on average total volatility is not significantly different than that of net inflows. These results suggest that net flow is positively associated with average total volatility, and this association is not asymmetric for net inflows and outflows. We also document a positive association between return and average volatility, which is evident from a positive significant coefficient estimate for absolute value of market return (|Return|). This association is also not asymmetric for positive and negative returns because the coefficient of the term without the absolute value is insignificant for most of the specifications.

Our findings that net flow is positively associated with average total volatility and that this association is not asymmetric for net inflows and outflows remain qualitatively the same under the control of size, liquidity and volatility persistency effects in different models. Our results conform with the implications of the asymmetric information hypothesis and are in accordance with empirical studies documenting that trading or order imbalance has a role in explaining volatility (Chan and Fong, 2000; Wu and Xu, 2000; Chordia et al., 2002). In our study, the foreign trading imbalance on either the purchase or the sale side could be interpreted as an indication of private information held by foreign traders, which may cause market participants to adjust prices accordingly and thus induce volatility.

\section{VOLATILITY COMPONENTS AND FOREIGN EQUITY TRADING}

After having analysed the average total volatility of stocks, our next focal point is to examine in which channels net flow affects average total volatility. Equation (8) shows that the average total volatility of stocks in a country is composed of systematic components such as 
TABLE 4

Average Total Volatility, $\sigma_{a_{l t}}^{2}$, and Foreign Equity Trading

\begin{tabular}{|c|c|c|c|c|}
\hline & (I) & (II) & (III) & $(I V)$ \\
\hline Netflow & $\begin{array}{c}-0.148 \\
(-0.744)\end{array}$ & $\begin{array}{c}-0.078 \\
(-0.362)\end{array}$ & $\begin{array}{c}-0.186 \\
(-0.719)\end{array}$ & $\begin{array}{c}-0.201 \\
(-0.792)\end{array}$ \\
\hline $\mid$ Netflow $\mid$ & $\begin{array}{l}0.748 \\
(3.473) * * *\end{array}$ & $\begin{array}{l}0.904 \\
(3.428) * * *\end{array}$ & $\begin{array}{l}0.873 \\
(3.252)^{* * *}\end{array}$ & $\begin{array}{l}0.893 \\
(3.498)^{* * *}\end{array}$ \\
\hline Return & $\begin{array}{l}-0.060 \\
(-3.498) * * *\end{array}$ & $\begin{array}{l}-0.040 \\
(-1.635)\end{array}$ & $\begin{array}{l}-0.025 \\
(-0.782)\end{array}$ & $\begin{array}{l}-0.023 \\
(-0.714)\end{array}$ \\
\hline |Return| & $\begin{array}{l}0.185 \\
(5.115)^{* * *}\end{array}$ & $\begin{array}{l}0.204 \\
(4.806) * * *\end{array}$ & $\begin{array}{l}0.191 \\
(4.165)^{* * *}\end{array}$ & $\begin{array}{l}0.186 \\
(5.175)^{* * *}\end{array}$ \\
\hline TO & & $\begin{array}{l}-0.064 \\
(-1.202)\end{array}$ & $\begin{array}{l}-0.070 \\
(-1.289)\end{array}$ & $\begin{array}{l}-0.072 \\
(-1.291)^{* *}\end{array}$ \\
\hline Size & & & $\begin{array}{l}-0.014 \\
(-0.753)\end{array}$ & $\begin{array}{l}-0.014 \\
(-0.708)\end{array}$ \\
\hline$\sigma_{a_{l t}}^{2}(-1)$ & $\begin{array}{c}0.083 \\
(0.803)\end{array}$ & $\begin{array}{c}0.152 \\
(1.248)\end{array}$ & $\begin{array}{c}0.140 \\
(1.131)\end{array}$ & $\begin{array}{c}0.135 \\
(0.804)\end{array}$ \\
\hline$\sigma_{a_{l t}}^{2}(-2)$ & $\begin{array}{l}0.330 \\
(6.446) * * *\end{array}$ & $\begin{array}{l}0.276 \\
(3.928) * * *\end{array}$ & $\begin{array}{l}0.285 \\
(3.990) * * *\end{array}$ & $\begin{array}{l}0.293 \\
(3.840) * * *\end{array}$ \\
\hline$\sigma_{a_{l t}}^{2}(-3)$ & & & & $\begin{array}{c}0.014 \\
(0.176)\end{array}$ \\
\hline$\sigma_{a_{l t}}^{2}(-4)$ & & & & $\begin{array}{l}-0.029 \\
(-0.543)\end{array}$ \\
\hline$c$ & $\begin{array}{l}-0.015 \\
(-1.952)^{*}\end{array}$ & $\begin{array}{l}-0.012 \\
(-1.483)\end{array}$ & $\begin{array}{l}-0.004 \\
(-0.355)\end{array}$ & $\begin{array}{l}-0.004 \\
(-0.256)\end{array}$ \\
\hline$J$ statistic & $\begin{array}{c}8.521 \\
{[0.860]}\end{array}$ & $\begin{array}{c}7.348 \\
{[0.883]}\end{array}$ & $\begin{array}{c}6.710 \\
{[0.876]}\end{array}$ & $\begin{array}{c}6.835 \\
{[0.868]}\end{array}$ \\
\hline Adj. $R^{2}$ & 0.419 & 0.336 & 0.361 & 0.350 \\
\hline
\end{tabular}

Notes:

(i) The following baseline time-series regression model is estimated by the generalised method of moments:

$$
\begin{aligned}
\hat{\sigma}_{a t}^{2}=c & +\beta_{1} \text { Netflow }_{t}+\beta_{2} \mid \text { Netflow }_{t} \mid+\beta_{3} \text { Return }_{t}+\beta_{4} \mid \text { Return }_{t} \mid \\
& +\beta_{5} \text { Size }_{t}+\beta_{6} \text { TO }_{t}+\beta_{7} \hat{\sigma}_{a, t-1}^{2}+\beta_{8} \hat{\sigma}_{a, t-2}^{2}+\beta_{9} \hat{\sigma}_{a, t-3}^{2}+\beta_{10} \hat{\sigma}_{a, t-4}^{2}+\eta_{t} .
\end{aligned}
$$

(ii) All variables are as defined in Table 3. (iii) The $t$-statistics are given in parentheses and are consistent with the arbitrary form of heteroscedasticity and autocorrelation. (iv) The brackets show the $p$ values of the $J$-test, which examines the null hypothesis that over-identifying restrictions are satisfied.

(v) $*$ and $* * *$ represent $10 \%$ and $1 \%$ significance levels, respectively.

global and local volatilities and of an unsystematic component, idiosyncratic volatility. In Turkey, local volatility is a likely channel in which net flow may show its impact because it is the largest component of average total volatility. Moreover, foreign investors may have information superiority over individual domestic investors because foreign investors are mainly institutional global investors and likely to have the ability to access and disseminate local market information. Average idiosyncratic volatility is another potential channel of influence. The existing literature documents that this variable exhibits an increasing trend over time (Campbell et al., 2001; Rubin and Smith, 2011). Its relationship with institutional ownership is investigated in $\mathrm{Xu}$ and Malkiel (2003). Like institutional investors, foreign investors may be better informed about the stocks that they invest in and may trade on their private information.

In an attempt to determine through which channels net flow affects average total volatility, we regress each of these components on Netflow, $\mid$ Netflow $\mid$ and the control variables. The 
results for each volatility component are presented in separate columns of Table 5. In Column (1), we observe a positive significant effect of |Netflow $\mid$ and a negative insignificant effect of Netflow for local volatility, as in the case for average total volatility. Obtaining similar results is not surprising given local volatility is the largest component of average total volatility (see Table 3). Column (2) shows the results for global volatility. We do not document any significant impact of net equity flow on global volatility, while the signs of the coefficients for |Netflow| and Netflow are similar to those reported for the average total and local volatilities. In the last column of Table 5, we document a positive significant effect of $\mid$ Netflow $\mid$ on idiosyncratic volatility. Different from local, global and average total volatilities, we report a negative significant effect of Netflow for idiosyncratic volatility, suggesting that net outflow has a more pronounced effect on idiosyncratic volatility. When Netflow is positive in value and thereby foreign funds inflow, the effect of net flow is determined by $\beta_{1}+\beta_{2}$, which is

TABLE 5

Volatility Components and Foreign Equity Trading

\begin{tabular}{lccc}
\hline & (1) Local & (2) Global & (3) Idiosyncratic \\
\hline Netflow & -0.144 & -0.003 & -0.166 \\
& $(-0.614)$ & $(-0.129)$ & $(-2.147)^{* *}$ \\
Netflow $\mid$ & 0.520 & 0.050 & 0.357 \\
& $(2.176)^{* *}$ & $(1.425)$ & $(4.262)^{* * *}$ \\
Return & -0.057 & -0.016 & -0.001 \\
& $(-1.790)^{*}$ & $(-4.800)^{* * *}$ & $(-0.030)$ \\
$\mid$ Return $\mid$ & 0.137 & 0.025 & 0.017 \\
& $(5.124)^{* * *}$ & $(3.725)^{* * *}$ & $(0.817)^{* * *}$ \\
TO & 0.015 & 0.010 & -0.018 \\
& $(0.320)$ & $(1.697)^{*}$ & $(-0.642)$ \\
Size & -0.011 & -0.002 & 0.022 \\
& $(-0.625)^{*}$ & $(-0.633)$ & $(2.546)^{* *}$ \\
volatility(-1) & 0.298 & 0.015 & 0.074 \\
& $(1.789)^{*}$ & $(0.190)$ & $(0.639)$ \\
volatility(-2) & 0.391 & 0.235 & 0.003 \\
& $(4.927)^{* * *}$ & $(3.571)^{* * *}$ & $(0.045)$ \\
volatility(-3) & -0.150 & -0.025 & 0.003 \\
& $(-1.790)^{*}$ & $(-0.333)$ & $(0.061)$ \\
volatility(-4) & -0.069 & -0.030 & 0.215 \\
& $(-1.185)$ & $(-0.478)$ & $(1.817)^{*}$ \\
c & -0.014 & -0.002 & -0.003 \\
& $(-1.162)$ & $(-1.533)$ & $(-0.536)$ \\
J statistic & 5.900 & 13.900 & 6.310 \\
Adj. $R^{2}$ & {$[0.921]$} & {$[0.836]$} & {$[0.900]$} \\
& 0.232 & 0.164 & 0.281 \\
\hline
\end{tabular}

Notes:

(i) The results of the regressions of volatility components on the net equity flow of foreign investors and on the previously defined control variables are presented in separate columns of the table. (ii) Column (1), Column (2) and Column (3) report the results of the time-series regressions, where the dependent variables are Local, Global and Idiosyncratic, respectively. volatility refers to the lagged values of the dependent variable in each column. (iii) Regression models are estimated by generalised method of moments. (iv) The $t$-statistics are given in parentheses and are consistent with the arbitrary form of heteroscedasticity and autocorrelation. (v) The brackets show the $p$ values of the $J$-test, which examines the null hypothesis that over-identifying restrictions are satisfied.

(vi) $* * *$ and $* * *$ represent $10 \%, 5 \%$ and $1 \%$ significance levels, respectively. 
$0.191(=-0.166+0.357)$, and thus there is a positive relation between net equity inflow and idiosyncratic volatility. When Netflow is negative in value and thus foreign funds outflow, there is again a positive association between net equity outflow and volatility, but the impact of net outflow on volatility is determined by $-\beta_{1}+\beta_{2}$, which is $0.523(=-(-0.166)$ $+0.357)$. From these calculations, an asymmetric effect of net outflow is revealed. Although there is a positive association between idiosyncratic volatility and net inflow and between idiosyncratic volatility and net outflow, this association is much stronger for net outflow. The excess impact of net outflow on idiosyncratic volatility can be interpreted as the overreaction of traders to foreigners' net sales in a panic environment.

Alternatively, several studies document that incorporation of firm-specific private information into stock prices by informed trading manifests itself in the form of high idiosyncratic volatility and find a positive relation between informed trading and idiosyncratic volatility (Morck et al., 2000; Durnev et al., 2003; Ferreira and Laux, 2007). Our findings of a positive relation between net inflow and idiosyncratic volatility and a more pronounced positive relation between net outflow and idiosyncratic volatility can therefore be driven by the informed trading of foreign investors. The stronger relation between net outflow and idiosyncratic volatility can also be interpreted as the revelation of relatively high firm-specific information in foreigners' sales. Overall, our findings of a positive relation between net flow and local volatility and between net flow and idiosyncratic volatility suggest that foreign investors mainly engage in the production of local-market information and firm-specific information.

\section{ROBUSTNESS CHECKS}

Our volatility decomposition methodology builds on the orthogonalised returns of the local index with respect to the global index. In such a process, the potential common effects driven by the local and the global factors may be attributed only to the global factor, overpurging the effects of the local factor. To check whether our results suffer from the overpurging problem, the order of orthogonalisation in the volatility decomposition process is reversed, and the return of the global index is orthogonalised with respect to the local index return. Under this order, we derive a new set of volatility components for average total volatility and use the new components as the dependent variables in our regression equations to examine the influence channels of net equity flow on average total volatility.

The first three columns of Table 6 provide the results of the regression of the volatility components, which are constructed under the alternative order of orthogonalisation, on Netflow, |Netflow $\mid$ and the control variables. Again, in each column, a different dependent variable (Local, Global and Idiosyncratic) is examined. Under the alternative order of orthogonalisation, INetflowl preserves its positive significant effect for the local and idiosyncratic volatilities while Netflow preserves its negative insignificant impact on local volatility and its negative significant impact on idiosyncratic volatility. No significant relationship between global volatility and net equity flow is documented, which is also the case for the former order of orthogonalisation. These findings are qualitatively the same as the ones of the previous section; therefore, we conclude that the effect of net equity flow on volatility is not sensitive to the order of orthogonalisation, and hence, the potential overpurging problem does not seriously affect our results.

As a final robustness check, we test whether the results for idiosyncratic volatility are sensitive to the definition of idiosyncratic volatility. For this purpose, we use the methodology of Bali et al. (2008), decomposing total risk into idiosyncratic and market risk and producing a 
TABLE 6

Alternative Volatility Components and Foreign Equity Trading

\begin{tabular}{|c|c|c|c|c|}
\hline & (1) Local & (2) Global & (3) Idiosyncratic & $\begin{array}{l}\text { (4) Model-free } \\
\text { Idiosyncratic }\end{array}$ \\
\hline Netflow & $\begin{array}{c}-0.004 \\
(-0.016)\end{array}$ & $\begin{array}{l}-0.000 \\
(-1.293)\end{array}$ & $\begin{array}{l}-0.195 \\
(-4.004) * * *\end{array}$ & $\begin{array}{l}-0.182 \\
(-2.306)^{* *}\end{array}$ \\
\hline $\mid$ Netflow| & $\begin{array}{l}0.632 \\
(2.207)^{* *}\end{array}$ & $\begin{array}{c}0.001 \\
(1.017)\end{array}$ & $\begin{array}{l}0.201 \\
(3.489) * * *\end{array}$ & $\begin{array}{l}0.349 \\
(3.040)^{* * *}\end{array}$ \\
\hline Return & $\begin{array}{l}-0.067 \\
(-1.701)^{*}\end{array}$ & $\begin{array}{c}0.000 \\
(0.663)\end{array}$ & $\begin{array}{l}0.019 \\
(3.991) * * *\end{array}$ & $\begin{array}{l}0.032 \\
(2.422)^{* *}\end{array}$ \\
\hline $\mid$ Return $\mid$ & $\begin{array}{l}0.168 \\
(4.508) * * *\end{array}$ & $\begin{array}{c}0.000 \\
(1.363)\end{array}$ & $\begin{array}{l}0.029 \\
(3.942)^{* * *}\end{array}$ & $\begin{array}{c}0.011 \\
(0.836)\end{array}$ \\
\hline TO & $\begin{array}{l}-0.003 \\
(-0.063)\end{array}$ & $\begin{array}{l}-0.000 \\
(-1.505)\end{array}$ & $\begin{array}{l}-0.046 \\
(-4.278) * * *\end{array}$ & $\begin{array}{l}-0.056 \\
(-2.121)^{* *}\end{array}$ \\
\hline Size & $\begin{array}{l}-0.008 \\
(-0.416)\end{array}$ & $\begin{array}{l}-0.000 \\
(-1.064)\end{array}$ & $\begin{array}{l}-0.000 \\
(-0.028)\end{array}$ & $\begin{array}{l}-0.005 \\
(-0.719)\end{array}$ \\
\hline volatility $(-1)$ & $\begin{array}{l}0.393 \\
(2.299)^{* *}\end{array}$ & $\begin{array}{l}0.224 \\
(3.670) * * *\end{array}$ & $\begin{array}{l}0.167 \\
(2.199) * *\end{array}$ & $\begin{array}{l}-0.069 \\
(-0.342)\end{array}$ \\
\hline volatility $(-2)$ & $\begin{array}{l}0.288 \\
(3.826) * * *\end{array}$ & $\begin{array}{l}-0.048 \\
(-4.907) * * *\end{array}$ & $\begin{array}{l}0.207 \\
(4.386) * * *\end{array}$ & $\begin{array}{c}0.152 \\
(1.368)\end{array}$ \\
\hline volatility $(-3)$ & $\begin{array}{l}-0.162 \\
(-2.017) * *\end{array}$ & $\begin{array}{l}0.084 \\
(5.099) * * *\end{array}$ & $\begin{array}{c}0.089 \\
(1.624)\end{array}$ & $\begin{array}{l}0.156 \\
(2.108)^{* *}\end{array}$ \\
\hline volatility $(-4)$ & $\begin{array}{l}-0.030 \\
(-0.511)\end{array}$ & $\begin{array}{l}-0.077 \\
(-1.736)^{*}\end{array}$ & $\begin{array}{l}-0.014 \\
(-0.237)\end{array}$ & $\begin{array}{l}0.148 \\
(2.478) * *\end{array}$ \\
\hline$c$ & $\begin{array}{l}-0.017 \\
(-1.216)\end{array}$ & $\begin{array}{c}0.000 \\
(1.441)\end{array}$ & $\begin{array}{l}0.007 \\
(2.743)^{* * *}\end{array}$ & $\begin{array}{l}0.009 \\
(1.710)^{*}\end{array}$ \\
\hline$J$ statistic & $\begin{array}{c}5.783 \\
{[0.927]}\end{array}$ & $\begin{array}{c}7.393 \\
{[0.995]}\end{array}$ & $\begin{array}{l}16.235 \\
{[0.702]}\end{array}$ & $\begin{array}{c}8.425 \\
{[0.751]}\end{array}$ \\
\hline Adj. $R^{2}$ & 0.203 & -0.117 & 0.533 & 0.218 \\
\hline
\end{tabular}

Notes:

(i) The results of the regression of the volatility components, which are constructed under the alternative order of orthogonalisation, on the net equity flow of foreign investors and on the other control variables are presented in Column (1), Column (2) and Column (3) of the table. Column (4) reports the results of the time-series regressions, where the dependent variable is the model-free idiosyncratic volatility. volatility refers to the lagged values of the dependent variable in each column. (ii) The $t$-statistics are given in parentheses and are consistent with the arbitrary form of heteroscedasticity and autocorrelation. (iii) The brackets show the $p$ values of the $J$-test, which examines the null hypothesis that over-identifying restrictions are satisfied.

(iv) $* * *$ and $* * *$ represent $10 \%, 5 \%$ and $1 \%$ significance levels, respectively.

model-independent measure of idiosyncratic risk. They define the model independent measure of idiosyncratic volatility as the difference between the risk for a portfolio consisting of perfectly correlated securities $\left(\rho_{\mathrm{ij}}=1\right)$ and the risk for a fully diversified portfolio. The intuition behind constructing this measure is based on the mean-variance portfolio theory and the gain from portfolio diversification. The risk for the former portfolio consists of systematic and unsystematic risks because there is no gain from constructing a portfolio with perfectly correlated securities. The latter portfolio's risk consists only of systematic risk because in a fully diversified portfolio unsystematic risk is diversified away. Hence, the difference between the risks for these portfolios results in a model-independent measure of average idiosyncratic risk. We form a value-weighted portfolio composed of the stocks in the IFC Global Index of Turkey as the non-diversified portfolio, assuming the correlation between stock returns to be one. We use the ISE-100 Index as the fully diversified portfolio and compute the average 
idiosyncratic risk for each month in the sample. Then, we repeat our tests with the alternative definition of idiosyncratic volatility. The results (reported in Column (4) of Table 6) show that $\mid$ Netflow $\mid$ has a positive significant coefficient estimate, whereas Netflow has a negative significant estimate. This suggests that net inflow and outflow are positively related with model-free idiosyncratic volatility and the relation between net outflow and model-free idiosyncratic volatility is asymmetrically stronger. Thus, our previous findings are also valid using a modelindependent measure of idiosyncratic volatility. In summary, our findings are robust to the alternative order of orthogonalisation in the volatility decomposition process and the alternative model-independent definition of idiosyncratic volatility.

\section{CONCLUSION}

It is important to understand the costs and benefits of foreign equity investment in stock exchanges, as this issue has crucial policy implications. The most important cost held to be brought by foreign equity investment is the increase in return volatility in emerging markets. In this study, we investigate the role of foreign equity trading in explaining average total volatility and its components in the ISE. The results show that average total volatility is positively related to foreign investors' net equity flow, even after controlling for market-wide price impacts, market development, liquidity and persistency in volatility. We also find that net equity flows show their effect on average total volatility through local and idiosyncratic volatilities; however, net sale has a much higher impact on idiosyncratic volatility. Our results suggest that foreign investors reveal firm-specific and country-specific information. We obtain similar results with the alternative order of orthogonalisation in the volatility decomposition process and with the alternative model-independent definition of idiosyncratic volatility. Our findings provide important implications for policymakers trying to stabilise their stock markets. Policies aiming at building and maintaining political stability and imposing regulations that restrict the rapid exit of foreign equity flows may dampen the destabilising effects of foreign investors especially on idiosyncratic volatility. Increased idiosyncratic volatility as a result of foreign trading is an important finding for investors, as it implies greater number of stocks is needed to achieve a given level of diversification. Increased local volatility also has implications for financial managers; it may boost firms' cost of capital.

\section{REFERENCES}

Admati, A. and P. Pfleiderer (1988), 'A Theory of Intraday Patterns: Volume and Price Variability', Review of Financial Studies, 1, 1, 3-40.

Bae, K., K. Chan and A. Ng (2004), 'Investibility and Return Volatility', Journal of Financial Economics, 71, 2, 239-63.

Bali, T. G., N. Cakici and H. Levy (2008), 'A Model-independent Measure of Aggregate Idiosyncratic Risk', Journal of Empirical Finance, 15, 5, 878-96.

Bekaert, G. and C. Harvey (2000), 'Foreign Speculators in Emerging Equity Markets', Journal of Finance, 55, 2, 565-613.

Bekaert, G. and C. Harvey (2002), 'Research in Emerging Markets Finance: Looking to the Future', Emerging Markets Review, 3, 4, 429-48.

Bekaert, G., C. Harvey and C. Lundblad (2003), 'Equity Market Liberalization in Emerging Markets', Journal of Financial Research, 26, 3, 275-99.

Bley, J. and M. Saad (2011), 'The Effect of Financial Liberalization on Stock-return Volatility in GCC Markets', Journal of International Financial Markets, Institutions and Money, 21, 5, 662-85. 
Campbell, J., M. Lettau, B. Malkiel and Y. Xu (2001), 'Have Individual Stocks Become More Volatile? An Empirical Exploration of Idiosyncratic Risk', Journal of Finance, 56, 1, 1-43.

Chan, K. and W. Fong (2000), 'Trade Size, Order Imbalance, and the Volatility-Volume Relation', Journal of Financial Economics, 57, 2, 247-73.

Chordia, T., R. Roll and A. Subrahmanyam (2002), 'Order Imbalance, Liquidity, and Market Returns', Journal of Financial Economics, 65, 1, 111-30.

Conover, M. (2011), 'Investment Issues in Emerging Markets: A Review', Research Foundation Literature Reviews, 6, 1, 1-27.

Dahlquist, M. and G. Robertsson (2001), 'Direct Foreign Ownership, Institutional Investors, and Firm Characteristics', Journal of Financial Economics, 59, 3, 413-40.

De Santis, G. and S. Imrohoroglu (1997), 'Stock Returns and Volatility in Emerging Financial Markets', Journal of International Money and Finance, 16, 4, 561-79.

Durnev, A., R. Morck, B. Yeung and P. Zarowin (2003), 'Does Greater Firm-specific Return Variation Mean More or Less Informed Stock Pricing?` Journal of Accounting Research, 41, 5, 797-836.

Edison, H. J. and F. E. Warnock (2003), 'A Simple Measure of the Intensity of Capital Controls', Journal of Empirical Finance, 10, 1, 81-103.

Esqueda, O. A., T. A. Assefa and A. V. Mollick (2012), 'Financial Globalization and Stock Market Risk', Journal of International Financial Markets, Institutions and Money, 22, 1, 87-102.

Fama, E. F. and J. D. MacBeth (1973), 'Risk, Return and Equilibrium: Empirical Tests', Journal of Political Economy, 81, 3, 607-36.

Fernandes, N. and M. A. Ferreira (2008), 'Does International Cross-listing Improve the Information Environment?‘ Journal of Financial Economics, 88, 2, 216-44.

Ferreira, M. A. and P. M. Gama (2005), 'Have World, Country, and Industry Risks Changed over Time? An Investigation of the Volatility of Developed Stock Markets', Journal of Financial and Quantitative Analysis, 40, 1, 195-222.

Ferreira, M. A. and P. A. Laux (2007), 'Corporate Governance, Idiosyncratic Risk, and Information Flow', Journal of Finance, 62, 2, 951-89.

Grabel, L. (1995), 'Assessing the Impact of Financial Liberalization on Stock Market Volatility in Selected Developing Countries', Journal of Development Studies, 31, 6, 903-17.

Hamao, Y. and J. Mei (2001), 'Living with the Enemy: An Analysis of Foreign Investment in the Japanese Equity Market', Journal of International Money and Finance, 20, 5, 715-35.

Hargis, K. (2002), 'Forms of Foreign Investment Liberalization and Risk in Emerging Markets', Journal of Financial Research, 25, 1, 19-38.

Karpoff, J. M. (1987), 'The Relation between Price Changes and Trading Volume: A Survey', Journal of Financial and Quantitative Analysis, 22, 1, 109-26.

Kim, H. and V. Singal (2000), 'Stock Market Openings: Experience of Emerging Economies', Journal of Business, 73, 1, 25-66.

Kyle, A. (1985), 'Continuous Auctions and Insider Trading', Econometrica, 53, 6, 1315-35.

Li, D., Q. N. Nguyen, P. K. Pham and S. X. Wei (2011), 'Large Foreign Ownership and Firm-level Stock Return Volatility in Emerging Markets', Journal of Financial and Quantitative Analysis, 46, 4, 1127-55.

McLean, R. D., J. Pontiff and M. Zhao (2011), 'Equity Market Liberalization, Fundamental Volatility, and Capital Raising', Working Paper (Alberta: University of Alberta).

Morck, R., B. Yeung and W. Yu (2000), 'The Information Content of Stock Markets: Why Do Emerging Markets Have Synchronous Stock Price Movements?' Journal of Financial Economics, 58, 1, 215-60.

Pavabutr, P. and H. Yan (2007), 'The Impact of Foreign Portfolio Flows on Emerging Market Volatility: Evidence from Thailand', Australian Journal of Management, 32, 2, 345-67.

Piotroski, J. D. and D. T. Roulstone (2004), 'The Influence of Analysts, Institutional Investors and Insiders on the Incorporation of Market, Industry and Firm-specific Information into Stock Prices', The Accounting Review, 79, 4, 1119-51.

Rhee, S. G. and J. Wang (2009), 'Foreign Institutional Ownership and Stock Market Liquidity: Evidence from Indonesia', Journal of Banking and Finance, 33, 7, 1312-24.

Rubin, A. and D. R. Smith (2011), 'Comparing Different Explanations of the Volatility Trend', Journal of Banking and Finance, 35, 6, 1581-97. 
Sarkissian, S. and M. J. Schill (2009), 'Are There Permanent Valuation Gains to Overseas Listing? Evidence from Market Sequencing and Selection', The Review of Financial Studies, 22, 1, 371-412.

Stiglitz, J. (2004), 'Capital Market Liberalization, Globalization, and the IMF', Oxford Review of Economic Policy, 20, 1, 57-71.

The Association of Capital Market Intermediary Institutions of Turkey (2007), Türkiye Sermaye Piyasas1 2006: Sermaye Piyasasında Gelişmeler - Yatırımc1 Analizi - Arac1 Kurumlar (İstanbul: Graphis).

The Association of Capital Market Intermediary Institutions of Turkey (2008), Türkiye Sermaye Piyasas1 2007: Sermaye Piyasasında Gelişmeler - Yatırımc1 Analizi - Arac1 Kurumlar (İstanbul: Graphis).

Umutlu, M., A. Altay-Salih and L. Akdeniz (2010a), 'Does ADR Listing Affect the Dynamics of Volatility in Emerging Markets?' Finance a Uver-Czech Journal of Economics and Finance, 60, 2, 122-37.

Umutlu, M., L. Akdeniz and A. Altay-Salih (2010b), 'The Degree of Financial Liberalization and Aggregated Stock-return Volatility in Emerging Markets', Journal of Banking and Finance, 34, 3, 509-21.

Wang, J. (2007), 'Foreign Equity Trading and Emerging Market Volatility: Evidence from Indonesia and Thailand', Journal of Development Economics, 84, 2, 798-811.

Wu, C. and X. E. Xu (2000), 'Return Volatility, Trading Imbalance and the Information Content of Volume', Review of Quantitative Finance and Accounting, 14, 2, 131-53.

$\mathrm{Xu}$, Y. and B. G. Malkiel (2003), 'Investigating the Behavior of Idiosyncratic Volatility', Journal of Business, 76, 4, 613-44. 